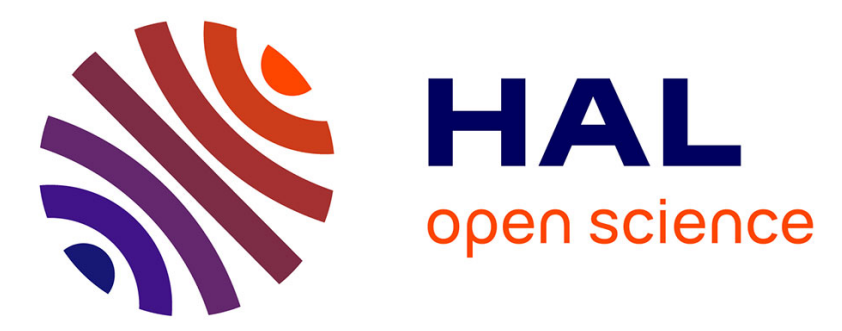

\title{
Synergy between Metallic and Oxidized Pt Sites Unravelled during Room Temperature CO Oxidation on Pt/Ceria
}

Frédéric Meunier, L. Cardenas, Helena Kaper, Břetislav Šmíd, Mykhailo

Vorokhta, Rémi Grosjean, Daniel Aubert, Kassiogé Dembele, Thomas

Lunkenbein

\section{To cite this version:}

Frédéric Meunier, L. Cardenas, Helena Kaper, Břetislav Šmíd, Mykhailo Vorokhta, et al.. Synergy between Metallic and Oxidized Pt Sites Unravelled during Room Temperature CO Oxidation on Pt/Ceria. Angewandte Chemie International Edition, 2021, 60 (7), pp.3799-3805. 10.1002/anie.202013223 . hal-03105968

\section{HAL Id: hal-03105968 \\ https://hal.science/hal-03105968}

Submitted on 3 Mar 2021

HAL is a multi-disciplinary open access archive for the deposit and dissemination of scientific research documents, whether they are published or not. The documents may come from teaching and research institutions in France or abroad, or from public or private research centers.
L'archive ouverte pluridisciplinaire HAL, est destinée au dépôt et à la diffusion de documents scientifiques de niveau recherche, publiés ou non, émanant des établissements d'enseignement et de recherche français ou étrangers, des laboratoires publics ou privés. 


\title{
Synergy between Metallic and Oxidized Pt Sites Unravelled during Room Temperature CO Oxidation on Pt/Ceria
}

\author{
Frederic C. Meunier ${ }^{*[a]}$, Luis Cardenas, ${ }^{[a]}$ Helena Kaper ${ }^{*[b]}$, Břetislav Šmíd, ${ }^{[c]}$ Mykhailo Vorokhta, ${ }^{[c]}$ Rémi \\ Grosjean, ${ }^{[b]}$ Daniel Aubert, ${ }^{[b]}$ Kassiogé Dembélé, ${ }^{[d]}$ Thomas Lunkenbein ${ }^{[d]}$
}

[a] Dr. F. C. Meunier, Dr. Cardenas,

Univ Lyon, Université Claude Bernard Lyon

CNRS, IRCELYON, 2 Av. Albert Einstein, 69626 Villeurbanne (France).

E-mail: fcm@ircelyon.univ-lyon1.fr

[b] Dr. H. Kaper, D. Aubert, Dr. R. Grosjean

Ceramic Synthesis and Functionalization Laboratory, UMR 3080, CNRS/Saint-Gobain CREE, Saint-Gobain Research Provence,

550 Ave Alphonse Jauffret, 84300 Cavaillon, France.

E-mail: helena.kaper@saint-gobain.com

[c] Dr. B. Šmíd, Dr. M. Vorokhta

Charles University, Department of Surface and Plasma Science, Faculty of Mathematics and Physics Institution

$\checkmark$ Holešovičkách 2, 18000 Prague 8, Czech Republic.

[d] Dr. T. Lunkenbein, D. K. Dembélé

Fritz-Haber-Institut der Max-Planck-Gesellschaft, Department of Inorganic Chemistry

Faradayweg 4-6, 14195 Berlin, Germany

\begin{abstract}
Pt-based materials are widely used as heterogeneous catalysts, in particular for pollutant removal applications. The nature of the active $\mathrm{Pt}$ phase responsible for $\mathrm{CO}$ oxidation has long been investigated with a view at designing more efficient formulations. The state of $\mathrm{Pt}$ has often been proposed to differ depending on experimental conditions, e.g. metallic $\mathrm{Pt}$ poisoned with $\mathrm{CO}$ being present at lower temperature before light-off, while an oxidized $\mathrm{Pt}$ surface prevails above light-off temperature. In stark contrast with all previous reports, we show here that both metallic and oxidized Pt are present in similar proportions under reaction conditions at the surface of ca. $1 \mathrm{~nm}$ nanoparticles showing high activity at $30{ }^{\circ} \mathrm{C}$. The simultaneous presence of metallic and oxidized Pt enables a synergy between these phases. The main role of metallic Pt phase is to provide strong adsorption sites for $\mathrm{CO}$, while that of oxidized $\mathrm{Pt}$ supposedly supplies reactive oxygen. Our results emphasize the complex dual oxidic-metallic nature of supported Pt catalysts and its evolving nature under reaction conditions, warranting a whole rethink of the mechanism of other reaction and metals, particularly redox and electrochemical reactions.
\end{abstract}

\section{Introduction}

Understanding metal speciation is essential for the design of atom-efficient catalysts. ${ }^{[1-3]}$ The nature of the active form of $\mathrm{Pt}$ for $\mathrm{CO}$ oxidation has been widely discussed, with a renewed recent interest following the preparation of so-called single atom catalysts. $^{[4-6]}$ Surface science ${ }^{[7-9]}$ and X-ray absorption spectroscopy techniques ${ }^{[10-12]}$ have been instrumental in unravelling the changing nature of $\mathrm{Pt}$ single crystals and nanoparticles depending on experimental conditions.
In short, two different regimes can be observed depending on the partial pressure ratio $\mathrm{P}(\mathrm{CO}) / \mathrm{P}\left(\mathrm{O}_{2}\right)$ and the temperature. The low activity regime is associated with a $\mathrm{CO}$ poisoned metallic surface characterized by a high apparent activation energy (between 80 and $176 \mathrm{~kJ} \mathrm{~mol}^{-1}$ ) with the ratedetermining step being $\mathrm{CO}$ desorption from surface sites to enable $\mathrm{O}_{2}$ adsorption. Recently, Gänzler et al. showed that the $\mathrm{CO}$ poisoning on $\mathrm{Pt}$ can be circumvented by oxygen supply from the ceria, thus explaining the better performance of ceria supports at low temperatures. ${ }^{[13]}$ Typical reaction orders are negative in $\mathrm{CO}$ (often -1 ) and positive in $\mathrm{O}_{2}$ (often +1 ). ${ }^{[9,14,15]}$

The metallic or oxidized nature of the high activity regime, often observed after a so-called light-off at higher temperature, is more controversial. This controversy partly arises from (i) the difficulty in controlling temperature and the potential presence of mass transfer limitations in the highly active regime and (ii) the role of the support in the stabilization of a more active form of $\mathrm{Pt}$, which has been proposed to be oxidic. ${ }^{[10,11,16]}$ The latter point contrasts with earlier reports that oxidic Pt exhibited a lower activity than that of metallic Pt surfaces. ${ }^{[12,17]}$ Whatever the exact nature of $\mathrm{Pt}$ in the high activity regime, this domain is commonly characterized by a lower activation energy $\left(30-60 \mathrm{~kJ} \mathrm{~mol}^{-1}\right)$ and fractional positive reaction orders for both $\mathrm{CO}$ and $\mathrm{O}_{2}{ }^{[8,9]}$

IR spectroscopy is commonly used to investigate the nature of $\mathrm{Pt}$ surfaces through the analysis of the wavenumbers of adsorbed CO, although spectral interpretation is not trivial. ${ }^{[18-20]}$ The stretching frequency $\mathrm{v}(\mathrm{CO})$ is affected by the Pt coordination number ${ }^{[21]}$ and oxidation state, ${ }^{[22-24]} \mathrm{CO}$ adsorption modes, ${ }^{[20,25]}$ and lateral interactions ${ }^{[4]}$ Somorjai and co-workers noted several types of adsorbed $\mathrm{CO}$ on $\mathrm{Pt}(111)$ surface during $\mathrm{CO}+\mathrm{O}_{2}$ reaction. ${ }^{[8]}$ Linear species at $2100 \mathrm{~cm}^{-1}$ are the main species present in the low activity metallic regime and are reaction inhibitors rather than spectators or reaction intermediates. The 
reaction intermediate is a species present at defect sites absorbing at ca. $2045 \mathrm{~cm}^{-1}$, which is present both in the low and high activity regime. The $2100 \mathrm{~cm}^{-1}$ inhibiting species are not observed at all in the high activity regime, in contrast to new bands at 2130 and $2240 \mathrm{~cm}^{-1}$ that indicate the presence of oxidized $\mathrm{Pt}$ sites.

Oxide-supported single atom $\mathrm{Pt}$ species, presumably positively charged $\mathrm{Pt}^{\mathrm{n}+}$, lead to bands around $2105 \pm 10 \mathrm{~cm}^{-1} \cdot{ }^{[1,2,5,26-28]}$ In some cases the $\mathrm{CO}$ adsorbed on single atom species can be discriminated from those adsorbed on Pt nanoparticles by the fact that the latter are readily removed through oxidation by $\mathrm{O}_{2}$ even at room temperature, while the $\mathrm{CO}$ adsorbed on single atoms is unreactive. ${ }^{[1]}$ The poor activity of $\mathrm{Pt}$ single atoms on ceria is further stressed by several groups. ${ }^{[16,27,29,30]}$ In contrast, metallic $\mathrm{Pt}$ nanoparticles interacting with oxygen from ceria ${ }^{[31-34]}$ and supported $\mathrm{PtO}_{\mathrm{x}}$ clusters ${ }^{[16,35]}$ are proposed as highly reactive species.

The present investigation focuses on $\mathrm{Pt} / \mathrm{CeO}_{2}$ catalysts composed of $\mathrm{Pt}$ nanoparticles supported on nanosized ceria prepared according to a method reported earlier. ${ }^{[36]}$ These materials are active at room temperature for $\mathrm{CO}$ oxidation and the activity is even increased in the presence of water. Our main aims are to investigate the natures of (i) the active Pt phase and (ii) the main reaction intermediates. We shall show, firstly, that the most active form of the catalyst actually involves the simultaneous presence of metallic and oxidic Pt. Secondly, we demonstrate by quantitative IR spectroscopy that the main reaction intermediates are carbonyls adsorbed on the metallic Pt phase. These carbonyls may react with oxygen from the $\mathrm{Pt}$ oxide phase or ceria, depending upon availability. Our observations help to rationalize apparently conflicting reports on similar catalysts about the origin of the oxygen used to oxidize $\mathrm{CO}$, e.g. from ceria ${ }^{[32]}$ or from oxidic $\mathrm{Pt},{ }^{[16]}$ as both routes may occur simultaneously.

\section{Results and Discussion}

The evolution of the reaction rate with time is monitored isothermally at $30{ }^{\circ} \mathrm{C}$ in the absence and presence of a small concentration of steam $(0.6 \mathrm{kPa})$ on powdered catalysts (Figure $1(\mathrm{~A})$ ). The reactions rate decreases rapidly within the first $100 \mathrm{~min}$ albeit slower in the wet case. Overall, the reaction rate in the wet case is ca. 2-6 times higher than that observed in the dry case. Water-promotion of $\mathrm{CO}$ oxidation at low temperature is well documented in the case of Au-based catalysts, ${ }^{[37,38]}$ and was also recently reported in the case of ceria-supported $\mathrm{Pt}^{\left[{ }^{[28]}\right.}$ In the following, our investigation focuses on the use of a wet feed, not only because of the observed higher activity and stability, but also because of its greater relevance to real-life applications. Any "dry" case data always remains ambiguous because water control at the ppm level is not trivial, while ppm-levels of water were shown to have dramatic effect in the case of Au. The faster deactivation noted in the dry feed (Figure $1 \mathrm{~A}$ ) could actually be due in part to a gradual water removal from the catalyst surface with time. In order to analyze the spent catalysts, the reaction was also carried out on a catalytic bench (see SI for details). The X-ray diffraction patterns of the as-prepared and spent $\mathrm{Pt} / \mathrm{CeO}_{2}$ (after $\mathrm{CO}$ oxidation for $12 \mathrm{~h}$ at $30^{\circ} \mathrm{C}$ in the presence of humidity) indicate the presence of cubic ceria (space group Fm-3m) only (Figure 1B). The crystallite size of ceria particles determined using Scherrer's equation for the diffraction peak located at $2 \Theta=29^{\circ}$ was $7.4 \mathrm{~nm}$. The surface area as derived from nitrogen physisorption (Figure $\mathrm{S} 1$ ) at $77 \mathrm{~K}$ is $112 \mathrm{~m}^{2} / \mathrm{g}$, which agrees with the X-ray diffraction results.
(B)
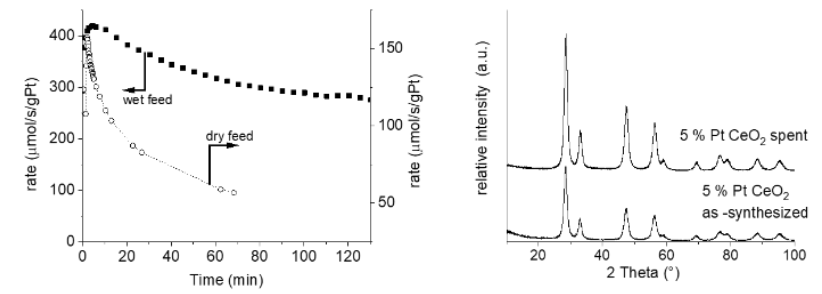

Figure 1. (A) $\mathrm{CO}$ oxidation of $5 \% \mathrm{Pt} \_\mathrm{CeO}_{2}$ after ex-situ reduction $\left(40 \% \mathrm{H}_{2} / \mathrm{He}\right.$ $300^{\circ} \mathrm{C}, 2 \mathrm{~h}$, atmospheric pressure) at $30^{\circ} \mathrm{C}$ under dry (right axis) and in the presence of humidity (left axis). Feed composition: $0.2 \% \mathrm{CO}+2 \% \mathrm{O}_{2}$ in $\mathrm{He}$, in the wet case $0.6 \%$ humidity is added. The measurement is done in a DRIFTS cell. (B) XRD pattern of the as-synthesized and spent catalyst.

No diffraction peaks from neither metallic $\mathrm{Pt}$ nor platinum oxide are visible, in both the as-synthesized and spent sample. This indicates that a high platinum dispersion is obtained.

The analysis of the HAADF-STEM images of the sample show that the fresh sample reduced at $300^{\circ} \mathrm{C}$ contains mostly Pt nanoparticles, which sizes are comprised between 0.6 and $1.5 \mathrm{~nm}$ (Figure 2.A-C), corresponding to a Pt dispersion of about $100 \%$. The particle size distribution is essentially identical after use for the $\mathrm{CO}$ oxidation in wet conditions at room temperature (Figure 2.D-E). A few single Pt atoms can also be observed (Figure 2B and E), as typical for this type of samples. Selected area electron diffraction (SAED, Figure S2) does not show Pt diffraction peaks on the reduced sample. This further confirms a high dispersion of the platinum species. However, the SAED analysis of the spent catalyst (Figure S3) evidences the presence of crystalline metallic $\mathrm{Pt}$, indicating that part of the $\mathrm{Pt}$ crystallizes and undergoes changes under reaction conditions, even though the overall dispersion is nearly unchanged. No evidence of oxidized $\mathrm{Pt}$ clusters can be obtained, though those may have been reduced in the high vacuum and under the electron beam of the electron microscope. ${ }^{[31]}$ These potential effects limit the informative depth of ex situ TEM studies to determine the structure of the catalytic active $\mathrm{Pt}$ species under the applied reaction conditions, warranting the use of other in situ or operando techniques to clarify further the nature of the active surface.

The evolution of the reactive species is further monitored by the corresponding IR bands of species adsorbed at the surface of the catalyst (Figure 3 ) over time at $30{ }^{\circ} \mathrm{C}$ and varying gas atmosphere with a view at unraveling structure-activity relationships. The corresponding rates measured in the DRIFTS cell is given in Figure 1 (A). For the DRIFTS experiment, the exsitu reduced sample is first exposed to the $\mathrm{O}_{2}+\mathrm{H}_{2} \mathrm{O}$ stream for 30 min before recording the IR background. $\mathrm{CO}$ is then introduced, taken as the origin of time.

The main bands observed (Figure 3.A) are located at 2055 $\mathrm{cm}^{-1}$ and $1822 \mathrm{~cm}^{-1}$, corresponding to linear (L-CO) and bridged (B-CO) carbonyls adsorbed on $\mathrm{Pt}^{0}{ }^{[21,25]}$ The $2055 \mathrm{~cm}^{-1}$ band is typical of $\mathrm{Pt}^{0}$ sites with a coordination numbers of 5 or $6,{ }^{[21]}$ consistent with the many edge sites present on our $1 \mathrm{~nm}$ diameter particles (Figure 2). The intensity of the bridged carbonyl band at $1822 \mathrm{~cm}^{-1}$ is unusually high in comparison to that of linear species for this size of nanoparticles. In addition, the band was asymmetric, exhibiting a shoulder below $1800 \mathrm{~cm}^{-1}$, suggesting the presence of various sites. 

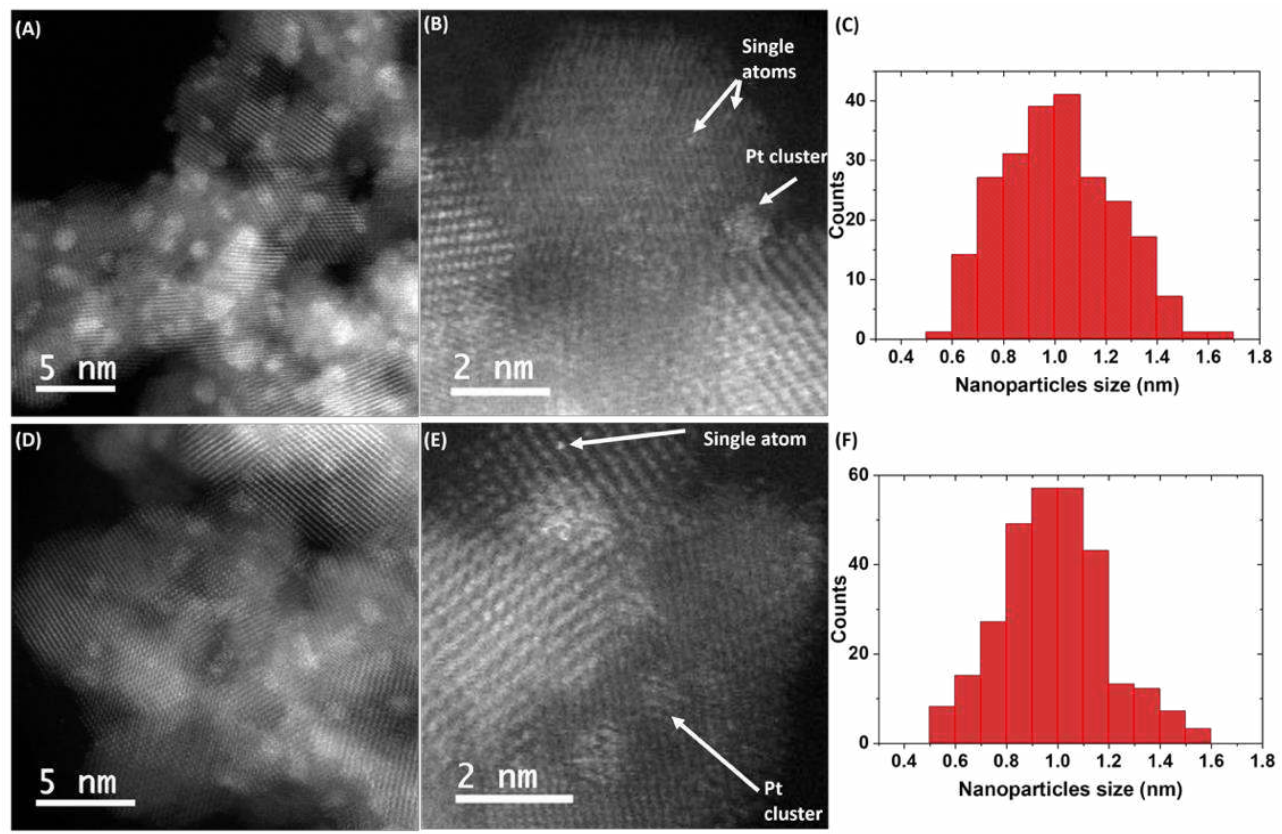

Figure 2. Representative HAADF-STEM images of the $\mathrm{Pt} / \mathrm{CeO}_{2}$ catalyst and the corresponding distribution of Pt particle sizes before (A-C) and after $\mathrm{CO}$ oxidation under wet conditions $(\mathrm{D}-\mathrm{E})$.

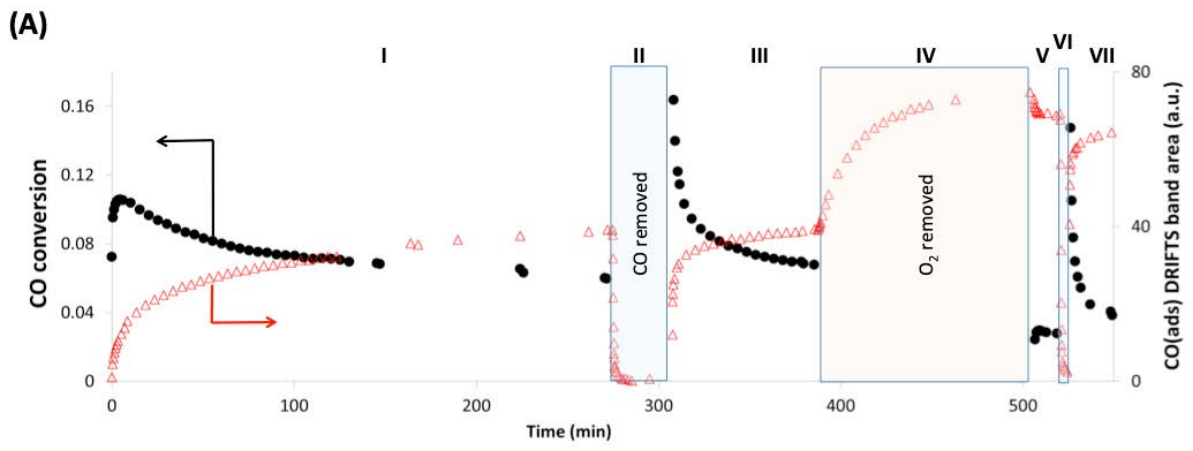

(B) Period I: full feed

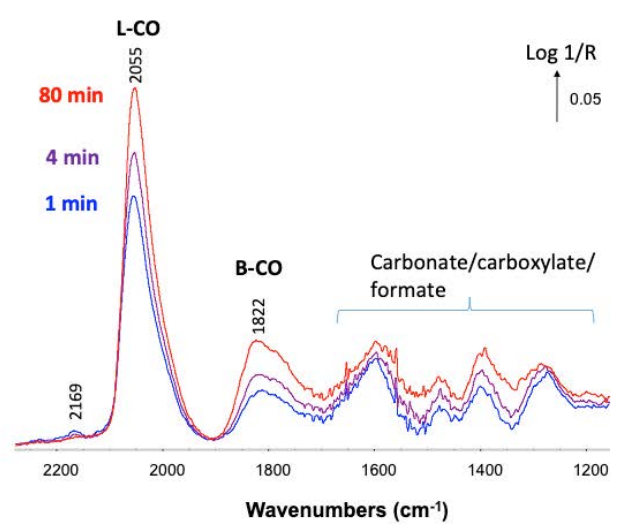

(C) Period IV : $\mathrm{O}_{2}$ removed

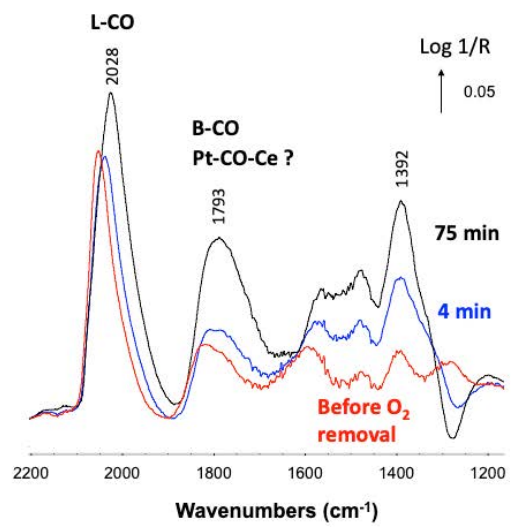

Figure 3. (A) CO conversion (full circles) and total carbonyl (= linear and bridged CO) DRIFTS signal (open triangles) measured during a typical CO oxidation experiment carried out over $\mathrm{Pt} / \mathrm{CeO}_{2}$ at $30{ }^{\circ} \mathrm{C}$ under $0.2 \% \mathrm{CO}+0.6 \%$ water $+2 \% \mathrm{O}_{2} / \mathrm{He}$ in a DRIFTS cell. Reaction products were analysed using an FT-IR gas cell. CO was removed from the feed during the periods noted II and $\mathrm{VI} . \mathrm{O}_{2}$ was removed from the feed during period noted IV. (B) Typical DRIFTS spectra collected during the first exposure to the full feed (period I) and (C) during the $\mathrm{O}_{2}$-free period IV. The sample spectrum collected under the CO-free feed before $\mathrm{CO}$ introduction was used as background for the whole experiment. The gas-phase spectrum of $\mathrm{CO}$ was subtracted. 
A weak band at $2169 \mathrm{~cm}^{-1}$ typical of linear $\mathrm{CO}$ of $\mathrm{Pt}^{1+}$ is observed only at short times on stream, indicating that this oxidized species was readily getting reduced upon $\mathrm{CO}$ introduction. ${ }^{[20,22-24]}$ It must be stressed that $\mathrm{CO}$ adsorption on $\mathrm{Pt}^{\mathrm{n+}}$ $\mathrm{n}>1$ (observed in the range $2220-2140 \mathrm{~cm}^{-1}$ ) is usually too weak to be observable at $30{ }^{\circ} \mathrm{C} .{ }^{[22-24]}$ Therefore, the absence of such bands in Figure 3.B should not be taken as a proof of the absence of highly oxidized Pt cations (single atoms or oxidic particles), i.e. the corresponding $\mathrm{CO}$ surface coverage could be too low to be observed. Other bands below $1700 \mathrm{~cm}^{-1}$ are typical of carbonate/carboxylate/formates and are difficult to resolve and not discussed further here.

Apart from the first few minutes on stream relating to some induction process, $\mathrm{CO}$ conversion gradually decreases, while the carbonyl signal gradually increases (Figure 3.A, section I. See Figure S4 for the individual contributions of L-CO and B-CO). A higher activity could yet be obtained after having removed $C O$ for short durations, although deactivation rates were then faster (Figure 3, periods III and VII).

CO conversion is plotted versus the IR band intensity of L$\mathrm{CO}$ and $\mathrm{B}-\mathrm{CO}$ to determine whether or not any unequivocal correlation existed between activity and these carbonyls (Figure 4). No unequivocal relation is observed between $C O$ conversion and the concentration of neither carbonyls, as the four periods considered led to different curves. This result indicates that either the expression of the rate is not a direct function of the surface concentration of $\mathrm{CO}$ adsorbed on metallic $\mathrm{Pt}$ sites or that the state of the catalyst surface was markedly modified over the various periods considered. We favor the latter explanation for the three following observations.
(A)

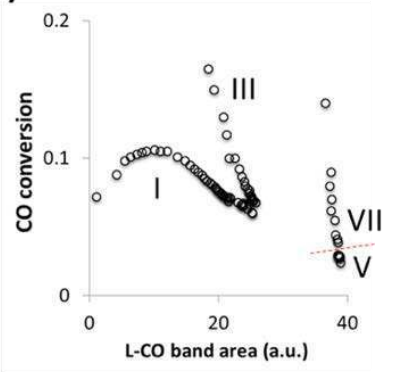

(B)

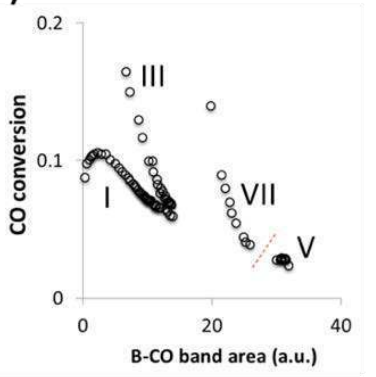

Figure 4. CO conversion plotted against the band area of $\mathrm{Pt}^{0}$-bound $(\mathrm{A}) \mathrm{L}-\mathrm{CO}$ and (B) B-CO corresponding to periods I, III, V and VII as indicated in Figure 3.A.

Firstly, the overall decays of $\mathrm{CO}$ conversion with increasing $\mathrm{Pt}^{0}-\mathrm{CO}$ signals for each of the reported periods (Figure 4) suggests that these carbonyls and $\mathrm{Pt}^{0}$ sites form at the expense of more reactive sites. Since carbonyls need to react with oxygen to form $\mathrm{CO}_{2}$, it is reasonable to propose that the disappearing reactive species was an oxygen-supplying entity such as $\mathrm{PtO}_{\mathrm{x}}$. This suggestion is supported by recent work showing that $\mathrm{PtO}_{x}$ clusters were highly reactive for low temperature $\mathrm{CO}$ oxidation. ${ }^{[16,35]}$
Secondly, the possible presence of $\mathrm{PtO}_{\mathrm{x}}$ species is evaluated by removing $\mathrm{O}_{2}$ from the feed, leaving the catalyst in the presence of steam and $\mathrm{CO}$. The intensity of both carbonyl bands L-CO and B-CO gradually increases to reach a level about double that obtained before removing $\mathrm{O}_{2}$ (see periods IV in Figure 3.A and S5 and Figure 3.C). This result indicates that these new carbonyls are formed on Pt sites previously not available for $\mathrm{CO}$ adsorption, either because of the presence of an adsorbed $\mathrm{O}$ on $\mathrm{Pt}^{0}$ or because the $\mathrm{Pt}$ is present as an oxide phase that does not adsorb $\mathrm{CO}$ at this temperature.

Thirdly, the marked modification of Pt oxidation state when varying feed composition was confirmed by in situ NAP-XPS. $\mathrm{O}_{2}$, $\mathrm{CO}$ and mixtures of those are injected inside the NAP-XPS analysis and reaction chamber at a total maximal pressure of 5 mbar. The samples were reduced ex-situ in order to be coherent with HAADF-STEM and DRIFTS analysis. The $\mathrm{Pt} / \mathrm{CeO}_{2}$ sample measured in the sole presence of $\mathrm{O}_{2}$ exhibits a mixture of oxidation states $\mathrm{Pt}^{0}, \mathrm{Pt}^{2+}$ and $\mathrm{Pt}^{4+}$ (Figure $5 \mathrm{~A}$ ). Metallic $\mathrm{Pt}^{0}$ represents a minority species under these conditions (Figure $5 \mathrm{~B}$ ). The corresponding NAP-XPS Ce $3 \mathrm{~d}$ levels spectra shows mostly $\mathrm{Ce}^{4+}$ species (see Figures S5-S7 in the NAP-XPS section in the supplementary). The proportions among $\mathrm{Pt}$ species were modified once $\mathrm{CO}$ was added to $\mathrm{O}_{2}$ : that of $\mathrm{Pt}^{4+}$ was reduced at the benefit of $\mathrm{Pt}^{0}$, while $\mathrm{Pt}^{2+}$ proportion was unaffected. Only $\mathrm{Pt}^{0}$ was then observed under $\mathrm{CO}$ once $\mathrm{O}_{2}$ is removed from the chamber. Bringing back $\mathrm{O}_{2}$ alongside $\mathrm{CO}$ leads to a strong reoxidation of the sample, with the $\mathrm{Pt}^{0}$ being now almost absent.

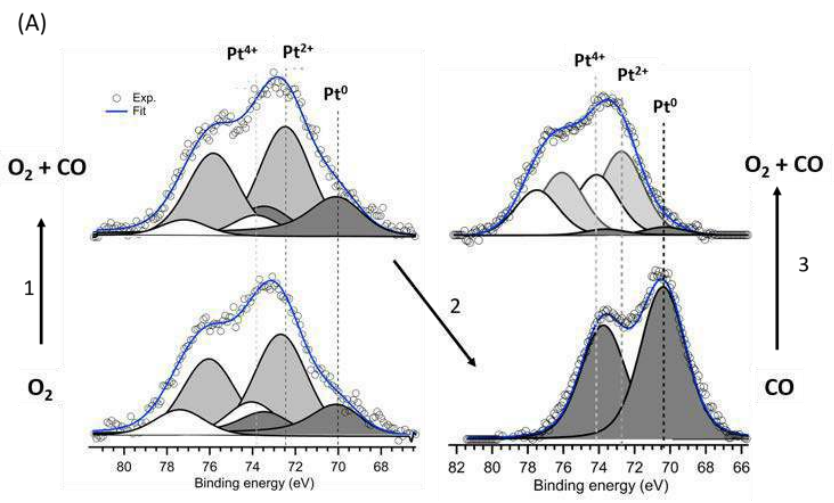

(B)

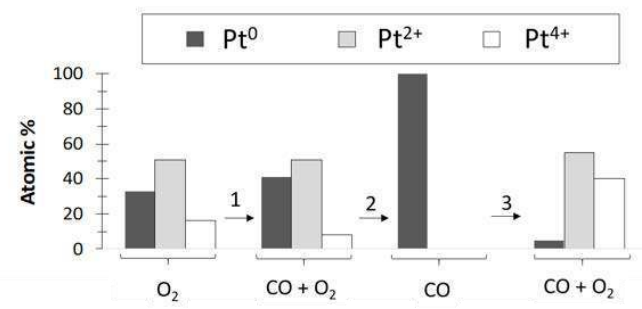

Figure 5. (A) NAP-XPS Pt $4 \mathrm{f}$ core levels measured over the $\mathrm{Pt} / \mathrm{CeO}_{2}$ sample at room temperature successively exposed to: $1.3 \mathrm{mbar}$ of $\mathrm{O}_{2}$ (bottom left), $5 \mathrm{mbar}$ of $\mathrm{O}_{2}+\mathrm{CO}$ (top left), $1.3 \mathrm{mbar}$ of $\mathrm{CO}$ (bottom right) and 5 mbar of $\mathrm{CO}+\mathrm{O}_{2}$ (top right). (B) Corresponding distribution of $\mathrm{Pt}$ oxidation states as a function of the gas composition. The gas flow rates of $\mathrm{CO}$ and $\mathrm{O}_{2}$ used were $0.4 \mathrm{ml} \mathrm{min}^{-1}$ and $0.85 \mathrm{ml} \mathrm{min}^{-1}$, ratio $\mathrm{pco} / \mathrm{po}_{2}=0.47$. The total pressure was $5 \mathrm{mbar}$. Note that no water vapor was introduced into the NAP-XPS chamber. Peak positions and shapes slightly evolved because of inhomogeneous charging effects. 
This final distribution of $\mathrm{Pt}$ states under $\mathrm{CO}+\mathrm{O}_{2}$ is quite different from that observed earlier, indicating that the sample oxidation state is history-dependent. The origin of this historydependent structure is yet unclear and may arise from various factors, including thermal effects (e.g. CO oxidation is highly exothermic) and the known ability of Pt to wet ceria to different extents depending on redox treatments. ${ }^{[12,31,33]}$

The NAP-XPS data (Figure 5) thus confirm our hypothesis that the structure of our $\mathrm{Pt} / \mathrm{CeO}_{2}$ greatly varies depending on reaction cycles, as suggested by the operando DRIFTS data (Figure 3 and 4). It is crucial to note that the fraction of oxidized $\mathrm{Pt}\left(\mathrm{Pt}^{2+}\right.$ and $\left.\mathrm{Pt}^{4+}\right)$ observed by NAP-XPS in the presence of the reagents, i.e. $\mathrm{CO}+\mathrm{O}_{2}$, is always higher than that of metallic $\mathrm{Pt}$ (Figure 5). This observation supports the conclusion obtained from the operando DRIFTS data that at steady-state reaction conditions a large fraction of $\mathrm{Pt}$ is in an oxidized state or covered with oxygen, and therefore electro-deficient.

The conclusion that the catalyst surface under reaction condition shows both metallic and oxidic $\mathrm{Pt}$ raises the question of which of this phase is most responsible for the activity, or whether a synergy exists. The measured apparent activation energy was $49 \pm 5 \mathrm{~kJ} / \mathrm{mol}$ and the reaction orders in $\mathrm{CO}$ and $\mathrm{O}_{2}$ were $0.35 \pm$ 0.04 and $0.19 \pm 0.03$, respectively (Figure 6 ). These values are fully consistent with those reported on oxidized $\mathrm{Pt}$ surfaces ${ }^{[10,11]}$ and not with those on metallic Pt. ${ }^{[9,14,15]}$ Therefore, we must conclude that the rate-determining step involves oxidized Pt.

(A)

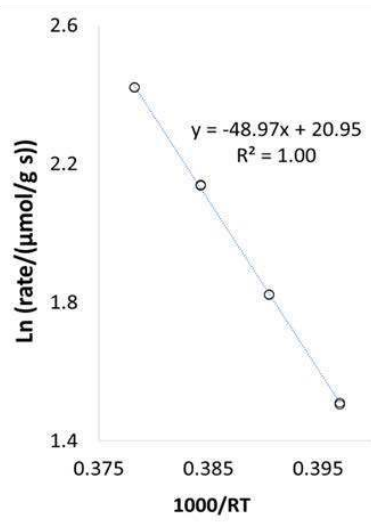

(B)

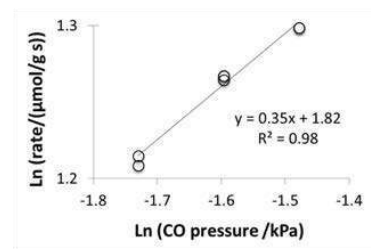

(C)

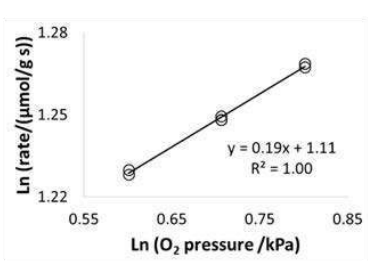

Figure 6. (A) Arrhenius plot and logarithmic plot of the reaction rate versus (B) $\mathrm{CO}$ pressure and $(\mathrm{C}) \mathrm{O}_{2}$ pressure used to determine the apparent activation energy and the reaction orders. Data were obtained at pseudo-steady-state at conversion lower than $20 \%$ using the DRIFTS cell. $\mathrm{T}=30-45^{\circ} \mathrm{C}$. The $\mathrm{CO}$ and $\mathrm{O}_{2}$ feed composition was slightly varied around that of the typical feed $(0.2 \%$ $\mathrm{CO}+0.6 \%$ water $+2 \% \mathrm{O}_{2} / \mathrm{He}$ ) at atmospheric pressure according to the pressure reported in the graph.

An important question remains on the role of metallic $\mathrm{Pt}$ and the associated carbonyl species that were observed by DRIFTS. It is possible that these carbonyls could react with oxygen from the $\mathrm{PtO}_{\mathrm{x}}$ species or from ceria, as proposed on similar materials. ${ }^{[29,36,37]}$ The data collected while removing $\mathrm{CO}$ from the feed (period II in Figure 3.A) were used to determine the rate constant of decomposition of L-CO and B-CO. Both species

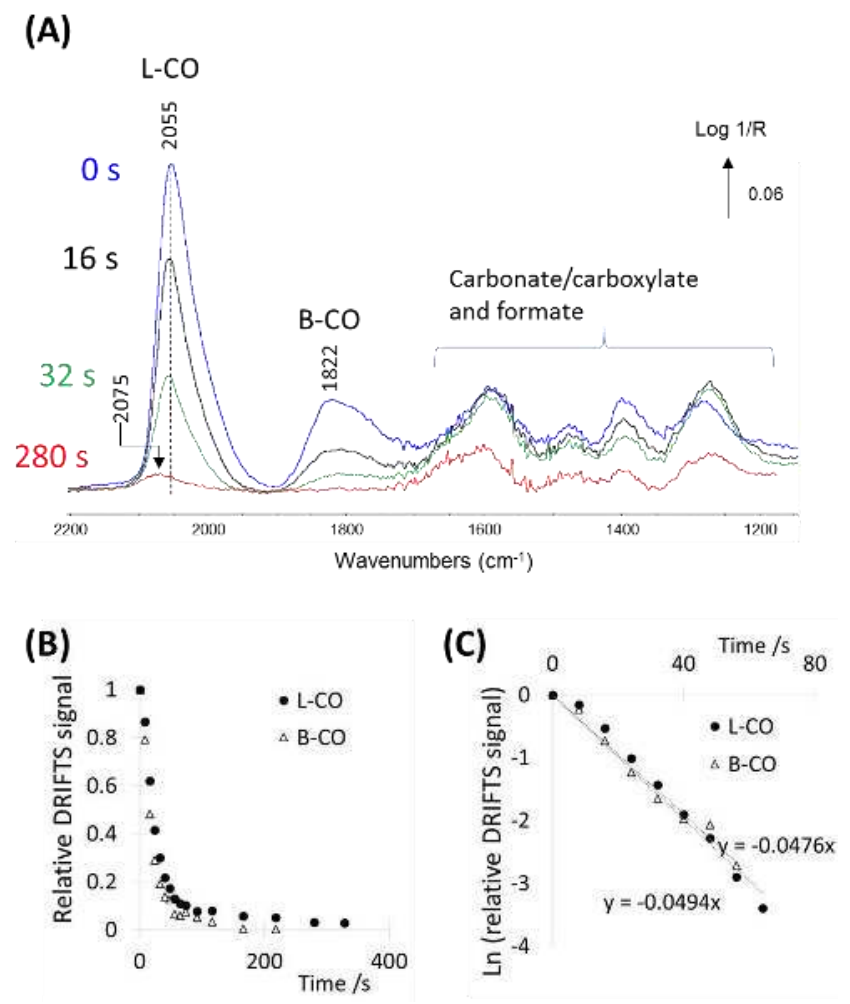

Figure 7. (A) DRIFTS spectra collected over the $\mathrm{Pt} / \mathrm{CeO}_{2}$ at $30{ }^{\circ} \mathrm{C}$ under $0.6 \%$ water $+2 \% \mathrm{O}_{2} / \mathrm{He}$ at various times following the removal of $\mathrm{CO}$. These data correspond to the region II in Figure 3.A. The band intensity of the linear L-CO and bridged $\mathrm{B}-\mathrm{CO}$ species was then plotted as a function of time in (B) normal or $(\mathrm{C})$ semi-logarithmic coordinates.

decompose uniformly with identical rates (Figure 7 and Table 1). This apparent similar reactivity could possibly be an artefact due to a fast surface transfer between the L-CO and B-CO forms, as observed on cobalt-based catalysts during $\mathrm{CO}$ hydrogenation. ${ }^{[41]}$

The specific decomposition rate of linear and bridged carbonyls can be calculated based on a Pt dispersion of ca. $100 \%$ and assuming that about $50 \%$ of the $\mathrm{Pt}$ atoms are in a metallic state (vide supra). The total concentration of carbonyls is thus half that of $\mathrm{Pt}$, also assuming a ratio 1:1 between surface metallic $\mathrm{Pt}$ and both linear and bridged carbonyls as a first approximation. The calculated decomposition rate of carbonyls, i.e. $6.1 \pm 3 \mu \mathrm{mol}$ $\mathrm{s}^{-1} \mathrm{~g}_{\mathrm{cata}}{ }^{-1}$, is similar to the rate of $\mathrm{CO}_{2}$ formation, i.e. $4.0 \pm 0.4 \mu \mathrm{mol}$ $\mathrm{s}^{-1} \mathrm{~g}_{\text {cata }}{ }^{-1}$, (Table 1). This observation strongly suggests that these $\mathrm{CO}$ species are main reaction intermediates in the formation of $\mathrm{CO}_{2}$ (or at least one of those, while the other could readily be surface-transferred to the other type of site to react).

This conclusion is consistent with the model proposed by Safonova and co-workers ${ }^{[32]}$ on a similar catalyst in which carbonyls adsorbed at the edge of metallic Pt nanoparticles of similar sizes reacted with oxygen from ceria. The TOF reported by these authors $\left(2 \times 10^{-2} \mathrm{~s}^{-1}\right.$ calculated at $\left.30^{\circ} \mathrm{C}\right)$ was actually similar to ours $\left(1.5 \times 10^{-2} \mathrm{~s}^{-1}\right)$. These authors did not consider the possibility of the presence of oxidized Pt species. 
Table 1. Parameters associated with carbonyl species bound to metallic Pt during $\mathrm{CO}$ oxidation at $30{ }^{\circ} \mathrm{C}$. The decomposition rate constants are derived from Figure 7. The rates of $\mathrm{CO}_{2}$ formation is calculated using the conversion values just before removing $\mathrm{CO}$ from the feed at the end of period I (see Figure 3.A)..

\begin{tabular}{|c|c|c|}
\hline Decomposition rate constant $\mathrm{k}(\mathrm{L}-\mathrm{CO})$ & $4.94 \pm 0.210^{-2}$ & $\mathrm{~s}^{-1}$ \\
\hline Decomposition rate constant $\mathrm{k}(\mathrm{B}-\mathrm{CO})$ & $4.76 \pm 0.210^{-2}$ & $\mathrm{~s}^{-1}$ \\
\hline Total Pt concentration & 251 & $\mu \mathrm{mol} / \mathrm{gcata}$ \\
\hline Total carbonyl concentration & 125 & $\mu \mathrm{mol} / \mathrm{gcata}$ \\
\hline Carbonyl decomposition rate & $6.1 \pm 3$ & $\begin{array}{l}\mu \mathrm{mol} /(\mathrm{s} \\
\text { gcata) }\end{array}$ \\
\hline Rate of $\mathrm{CO}_{2}$ production per $\mathbf{g}_{\text {catalyst }}$ & $4.0 \pm 0.4$ & $\begin{array}{l}\mu \mathrm{mol} /(\mathrm{s} \\
\text { gcata) }\end{array}$ \\
\hline Rate of $\mathrm{CO}_{2}$ production per $\mathrm{gPt}_{\mathrm{Pt}}$ & 79 & $\mu \mathrm{mol} / \mathrm{s} / \mathrm{gPt}_{\mathrm{Pt}}$ \\
\hline $\mathrm{TOF}\left(\mathrm{mol} \mathrm{CO} / 2\left(\mathrm{molpt}_{\mathrm{Pt}}\right)\right)$ & $1.510^{-2}$ & $\mathrm{~s}^{-1}$ \\
\hline
\end{tabular}

The TOF measured here $\left(1.5 \times 10^{-2} \mathrm{~s}^{-1}\right)$ is still significantly lower than that reported by Wang and co-workers ${ }^{[16]}\left(22 \times 10^{-2} \mathrm{~s}^{-1}\right)$ on a catalyst presenting only $\mathrm{PtO}_{x}$ species and no metallic $\mathrm{Pt}$. It is possible that such highly active species were present to some extent in our sample and especially account for the higher conversion observed at the beginning of the period I, III and VII (Figure 3.A). At the present time, it is not possible for us to conclude on the origin of the oxygen reacting with the $\mathrm{Pt}^{0}-\mathrm{CO}$ species, but it is likely coming from both ceria and $\mathrm{PtO}_{\mathrm{x}}$ species.

The mechanism most consistent with our data is thus a combination of those reported earlier on purely metallic or oxidic $\mathrm{Pt}$ and is depicted in Figure 8. We have clearly demonstrated that the carbonyls present at the surface of metallic $\mathrm{Pt}$ atoms can account for all the $\mathrm{CO}_{2}$ formed under reaction conditions (Table 1). We have also shown that about half of the Pt was present as oxidized $\mathrm{PtO}_{\mathrm{x}}$ under our conditions (see periods IV in Figure 3.A and S4 and Figure 3.C) and that the activity clearly declined with the reduction of this $\mathrm{PtO}_{x}$ phase into metallic $\mathrm{Pt}$ (Figure 4). Adsorbed carbonyls on $\mathrm{Pt}^{0}$ can likely react with both oxygen from ceria and oxygen from the $\mathrm{PtO}_{x}$ phase to produce $\mathrm{CO}_{2}$. We have also observed that the oxidation state of the Pt nanoparticles depended on the sequence of treatments (Figure 5), such as the order of reactant introduction.

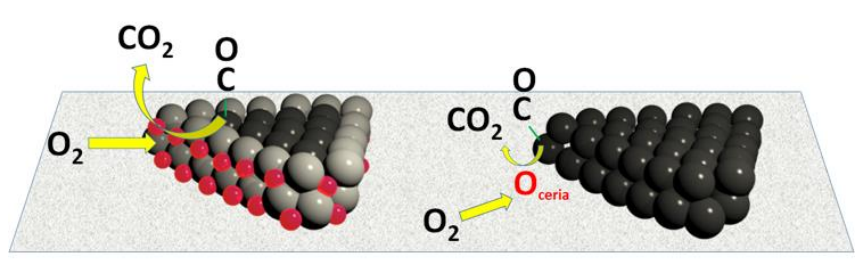

Figure 8. Schematic representation of the phases involved in $\mathrm{CO}$ oxidation at low temperature on $\mathrm{Pt} / \mathrm{CeO}_{2}$ : (Left) partially oxidized $\mathrm{Pt}$ nanoparticles enable reaction between $\mathrm{CO}$ adsorbed on metallic $\mathrm{Pt}$ sites and oxygen from $\mathrm{PtO}_{x}$ species. (Right) Fully reduced $\mathrm{Pt}$ enables reaction between $\mathrm{CO}$ adsorbed on $\mathrm{Pt}^{0}$ and oxygen supplied by the ceria support. Atom color code: $\mathrm{Pt}^{0}$ (black), oxidized $\mathrm{Pt}$ (grey), O (red). All $\mathrm{Pt}^{0}$ sites are covered by $\mathrm{CO}$ at room temperature, only one $\mathrm{CO}$ is represented, for the sake of clarity. The actual particle shape is not known and may change with feed composition.

\section{Conclusion}

In this work, we carefully analyze the active Pt species for room temperature $\mathrm{CO}$ oxidation of nanosized $\mathrm{Pt}$ on ceria using operando DRIFTS and NAP-XPS techniques. We can clearly identify the presence of both metallic and oxidized Pt during the reaction, suggesting a mechanism involving the two species. It is possible that the fraction of $\mathrm{Pt}$ remaining oxidized in the presence of $\mathrm{CO}$ could be the smallest nanoparticles (clusters) present, which should be less prone to get reduced because of strongest interaction with the support, and these might contribute to the catalytic performance by supplying oxygen to the reduced platinum particles. It is not possible for us to conclude on this matter that would require the preparation of a set of very narrow and stable $\mathrm{Pt}$ particle size distributions. Our observation underlines the versatility of $\mathrm{Pt}$ and ceria-based catalysts and rationalizes the difficulty in comparing data and mechanisms proposed by various groups, as catalyst structure is strongly history-dependent. More work is needed to determine the exact structure of the metallic and oxidic Pt phases, which are likely subnanometric labile domains strongly interacting with ceria that will require operando techniques such as EXAFS to capture their evolving nature. The co-existence of oxidic and metallic $\mathrm{Pt}$ domains has been proposed by Jacob and co-workers in the case of electrochemical systems and extended Pt surface DFT models. ${ }^{[22,43]}$ Also for methane oxidation on Pd catalysts the presence of both, oxidized and metallic $\mathrm{Pd}$ seem to enhance the performance, in particular in the presence of water vapour. ${ }^{[44]}$ Our work is in line with these recent findings and opens a new vision in the active nature of Pt catalysts where both metallic and oxidic Pt phases can coexist.

\section{Acknowledgements}

The authors acknowledge the CERIC-ERIC Consortium for the access to experimental facilities and financial support (grant number 20187010). RG and HK thank the FUI for funding the project "AIRCLEAN" under the AAP 22. MV and BS would like to thank the Czech Science Foundation for financial support under project no. 20-13573S.

Keywords: room temperature CO oxidation - operando DRIFTS - structure-reactivity relationship • NAP-XPS • platinum

[1] K. Ding, A. Gulec, A. M. Johnson, N. M Schweitzer, G. D. Stucky, L. D. Marks, P. C. Stair, Science (80-. ). 2015, 350, 189192.

[2] L. DeRita, S. Dai, K. Lopez-zepeda, N. Pham, G. W. Graham, X. Pan, P. Christopher, J. Am. Chem. Soc. 2017, 139, 14150-14165.

[3] J. C. Matsubu, V. N. Yang, P. Christopher, J. Am. Chem. Soc. 2015, 137, 3076-3084. 
[4] M. Flytzani-Stephanopoulos, B. C. Gates, Annu. Rev. Chem. Biomol. Eng. 2012, 3, 545-574.

[5] H. V. Thang, G. Pacchioni, L. DeRita, P. Christopher, J. Catal. 2018, 367, 104-114.

[6] A. J. Therrien, A. J. R. Hensley, M. D. Marcinkowski, R. Zhang, F. R. Lucci, B. Coughlin, A. C. Schilling, J. S. McEwen, E. C. H. Sykes, Nat. Catal. 2018, 1, 192-198.

[7] T. Engel, G. Ertl, Adv. Catal. 1979, 28, 178.

[8] X. Su, P. S. Cremer, Y. R. Shen, G. A. Somorjai, J. Am. Chem. Soc. 1997, 119, 3994-4000.

[9] G. Ertl, Surf. Sci. 1993, 288, 1-11.

[10] J. Singh, E. M. C. Alayon, M. Tromp, O. V. Safonova, P. Glatzel, M. Nachtegaal, R. Frahm, J. A. Van Bokhoven, Angew. Chemie - Int. Ed. 2008, 47, 9260-9264.

[11] P. Carlsson, L. Österlund, P. Thormählen, A. Palmqvist, 2004, 226, 422-434.

[12] A. M. Gänzler, M. Casapu, P. Vernoux, S. Loridant, F. J. Cadete Santos Aires, T. Epicier, B. Betz, R. Hoyer, J. D.

Grunwaldt, Angew. Chemie - Int. Ed. 2017, 56, 13078-13082.

[13] A. M. Gänzler, M. Casapu, D. E. Doronkin, F. Maurer, P. Lott, P. Glatzel, M.

Votsmeier, O. Deutschmann, J. D.

Grunwaldt, J. Phys. Chem. Lett. 2019, 10, 7698-7705.

[14] A. D. Allian, K. Takanabe, K. L. Fujdala, X. Hao, T. J. Truex, J. Cai, C. Buda, M. Neurock, E. Iglesia, J. Am. Chem. Soc. 2011, 133, 4498-4517.

[15] R. H. Venderbosch, W. Prins, W. P. M. Van Swaaij, Chem. Eng. Sci. 1998, 53, 3355-3366.

[16] H. Wang, J.-X. Liu, L. F. Allard, S. Lee, J. Liu, H. Li, J. Wang, J. Wang, S. H. Oh, W. Li, M. Flytzani-Stephanopoulos, M. Shen, B. R. Goldsmith, M. Yang, Nat. Commun. 2019, 10, 1-12.

[17] J. E. Turner, B. C. Sales, M. B. Maple, Surf. Sci. 1981, 103, 54-74.

[18] P. Hollins, Surf. Sci. Rep. 1992, 16, 51-94.

[19] H. A. Aleksandrov, K. M. Neyman, K. I. Hadjiivanov, G. N. Vayssilov, Phys. Chem. Chem. Phys. 2016, 18, 22108-22121.

[20] F. C. Meunier, R. Kdhir, N. Potrzebowska,
N. Perret, M. Besson, Inorg. Chem. 2019 , 58, 8021-8029.

[21] M. J. Kappers, J. H. van der Maas, Catal. Letters 1991, 10, 365-373.

[22] K. Chakarova, M. Mihaylov, K. Hadjiivanov, Catal. Commun. 2005, 6, 466-471.

[23] K. Chakarova, K. Hadjiivanov, G. Atanasova, K. Tenchev, J. Mol. Catal. A Chem. 2007, 264, 270-279.

[24] K. Chakarova, M. Mihaylov, K. Hadjiivanov, Microporous Mesoporous Mater. 2005, 81, 305-312.

[25] B. E. Hayden, A. M. Bradshaw, J. Electron Spectros. Relat. Phenomena 1983, 30, 51.

[26] J. Jones, H. Xiong, A. T. DeLaRiva, E. J. Peterson, H. Pham, S. R. Challa, G. Qi, S. Oh, M. H. Wiebenga, X. I. P. Hernández, Y. Wang, A. K. Datye, Science (80-. ). 2016, 353, 150-154.

[27] L. Nie, D. Mei, H. Xiong, B. Peng, Z. Ren, X. I. P. Hernandez, A. DeLaRiva, M. Wang, M. H. Engelhard, L. Kovarik, A. K. Datye, Y. Wang, Science (80-. ). 2017, 358, 1419-1423.

[28] C. Wang, X. K. Gu, H. Yan, Y. Lin, J. Li, D. Liu, W. X. Li, J. Lu, ACS Catal. 2017, 7, 887-891.

[29] F. Maurer, J. Jelic, J. Wang, A. Gänzler, P. Dolcet, C. Wöll, Y. Wang, F. Studt, M. Casapu, J.-D. Grunwaldt, Nat. Catal. 2020, DOI 10.1038/s41929-020-00508-7.

[30] C. Dessal, T. Len, F. Morfin, J. L. Rousset, M. Aouine, P. Afanasiev, L. Piccolo, ACS Catal. 2019, 9, 5752-5759.

[31] S. Gatla, D. Aubert, G. Agostini, O. Mathon, S. Pascarelli, T. Lunkenbein, M. G. Willinger, H. Kaper, ACS Catal. 2016, 6, 6151-6155.

[32] R. Kopelent, J. van Bokhoven, J. Szlachetko, J. Edebeli, C. Paun, M. Nachtegaal, O. V. Safonova, Angew. Chem. Int. Ed. 2015, 54, 8728-8731.

[33] A. M. Gänzler, M. Casapu, F. Maurer, H. Störmer, D. Gerthsen, G. Ferré, P. Vernoux, B. Bornmann, R. Frahm, V. Murzin, M. Nachtegaal, M. Votsmeier, J. D. Grunwaldt, ACS Catal. 2018, 8, 48004811.

[34] M. Cargnello, V. V. T. Doan-Nguyen, T. R. 
Gordon, R. E. Diaz, E. A. Stach, R. J.

Gorte, P. Fornasiero, C. B. Murray, Science (80-. ). 2013, 341, 771-773.

[35] J. Ke, W. Zhu, Y. Jiang, R. Si, Y.-J. Wang, S.-C. Li, C. Jin, H. Liu, W.-G. Song, C.-H. Yan, Y.-W. Zhang, ACS Catal. 2015, 5, 5164-5173.

[36] S. Gatla, D. Aubert, V. Flaud, R. Grosjean, T. Lunkenbein, Catal. Today 2019, 333, 105-112.

[37] M. Daté, M. Haruta, J. Catal. 2001, 201, 221-224.

[38] J. Saavedra, C. J. Pursell, B. D. Chandler, 2018, DOI 10.1021/jacs.7b12758.

[39] L. DeRita, J. Resasco, S. Dai, A. Boubnov, H. V. Thang, A. S. Hoffman, I. Ro, G. W. Graham, S. R. Bare, G. Pacchioni, X. Pan, P. Christopher, Nat. Mater. 2019, 18, 746751.

[40] A. Bruix, A. Migani, G. N. Vayssilov, K. M. Neyman, J. Libuda, F. Illas, Phys. Chem. Chem. Phys. 2011, 13, 1138411392.

[41] A. Paredes-Nunez, D. Lorito, L. Burel, D. Motta-Meira, G. Agostini, N. Guilhaume, Y. Schuurman, F. Meunier, Angew. Chemie - Int. Ed. 2018, 57, 547-550.

[42] D. Fantauzzi, S. Krick Calderón, J. E. Mueller, M. Grabau, C. Papp, H. P.

Steinrück, T. P. Senftle, A. C. T. van Duin, T. Jacob, Angew. Chemie - Int. Ed. 2017, 56, 2594-2598.

[43] A. Farkas, D. Fantauzzi, J. E. Mueller, T. Zhu, C. Papp, H. P. Steinrück, T. Jacob, J. Electron Spectros. Relat. Phenomena 2017, 221, 44-57.

[44] K. A. Karinshak, P. Lott, M. P. Harold, O. Deutschmann, ChemCatChem 2020, 12, 3712-3720. 